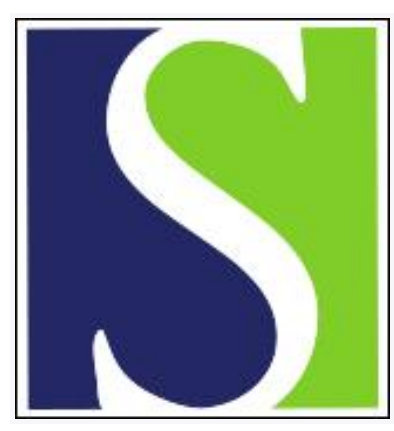

Scand J Work Environ Health 1980;6(3):230

https://doi.org/10.5271/sjweh.2612

Issue date: Sep 1980

\title{
Sawmill work and extrinsic allergic alveolitis.
}

by Belin L

Key terms: allergic alveolitis; extrinsic allergic alveolitis; letter to the editor; sawmill; sawmill work

This article in PubMed: www.ncbi.nlm.nih.gov/pubmed/6937828

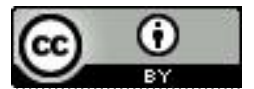


in case-referent studies. Am j epidemiol 103 (1976) 226-235.

5. Pacific Northwest Laboratory, Biology Dept. Study of the combined effects of smoking and inhalation of uranium ore dust, radon daughters and diesel oil exhaust fumes in hamsters and dogs: Final report. National Institute of Environmental Health Sciences, Richland, VA 1978. (HEW contract TD 0212).

\section{Olav Axelson \\ Department of Occupational Medicine University Hospital \\ S-581 85 Linköping, Sweden}

and

Lennart Sundell

Department of Occupational Medicine Regional Hospital

S-701 85 Örebro, Sweden

\section{Sawmill work and extrinsic allergic alveolitis}

Sir,

The authors of "Extrinsic Allergic Alveolitis in a Sawmill Worker" (vol 6, no 2, 1980 , pp 153-157) have apparently missed the fact that extrinsic allergic alveolitis, tentatively named wood trimmer's disease, has been described as a widespread and complicated health problem in the sawmill industry for the last 3 to $4 \mathrm{a}$ in Sweden.

With this Finnish report of one case the authors now take the opportunity to alert the readers about a "new health hazard in modern sawmill industry." If they had troubled themselves by reading any of the references given below, they would know that the problem has been recognized and subjected to much study - even reported at scientific meetings in Finland on two occasions (in 1977 and 1979). If attention had been paid to the Swedish data, an interesting discussion could have been given concerning the different findings of causative mold species to these reactions, which are probably the same in Sweden and Finland.
The serological data in the report do not provide information on whether antigen extracts representing Rhizopus, Paecilomyces and Mucor species were included in the precipitin analyses. Rhizopus has by far been found to be the dominating mold species in the trimming areas of Swedish sawmills, probably because of its very rapid growth at kiln drying temperatures in comparison with many other opportunistic spore producing molds. Finally, it would have been interesting to know how the authors relate their mold problem to the kiln drying procedure, which I assume has been employed for wood drying also in the saw mill in which their case worked. In Sweden we have mainly traced the problem to this operation in modern saw mills, and the technical schedules for the kiln drying are currently critically examined in order to create less favorable conditions for the opportunistic molds to grow during the drying process.

\section{References}

1. Belin L. Justerverkssjuka - ett aktuellt medicinskt problem inom svensk ságverksindustri. In: Institute of Occupational Health, ed. 26 Nordiska yrkeshygieniska mötet. Helsinki 1977, pp 138-139.

2. Belin L. Wood trimmer's disease - An allergic reaction to moulds in Swedish saw mills. J allergy clin immunol 61 (1978) 160 .

3. Belin L. Wood trimmer's disease - An allergic reaction to moulds in Swedish saw mills. In: European Academy of Allergology and Clinical Immunology, ed. Annual meeting of the European Academy of Allergology and Clinical Immunology, Helsinki 1979 , p. 50.

4. Belin L, Göransson K, Wimander K, Wåhlén P. "Justerverkssjuka" — en immunkomplexsjukdom inom svensk sågverksindustri. Arbetrskyddsstyrelsen, Stockholm 1976. (Utbildning 2:76).

5. Belin L, Wallentén $B$, Wimander $K$. Wood trimmer's disease from moulds on planks. Arbetsmiljö 10 B (1977) 19.

Lars Belin, MD

Occupational Health Centre and

Department of Allergology

First Medical Service

Sahlgren's Hospital

S-413 45 Göteborg, Sweden 


\section{Authors' reply}

Sir,

There is a clear difference between the clinical picture of our case and all those reported Swedish cases (called "Justerverkssjukan" or "wood trimmer's disease") that we are familiar with. In his chest radiograph, our patient had reversible lung infiltrations compatible to extrinsic allergic alveolitis (1), whereas no such infiltrations were reported in the Swedish cases. We thus feel that the Swedish cases do not fulfill the diagnostic criteria for extrinsic allergic alveolitis, but seem to have common features with, eg, "humidifier fever" (2).

Our report dealt with a case of real extrinsic allergic alveolitis, and therefore we thought that one reference to Swedish publications was enough. As can be seen from Dr. Belin's letter, most of his communications on wood trimmer's disease are abstracts which have appeared (with one exception) in publications not cited in computerized international literature search systems. We chose the case report by Bäck and Göransson as a reference because it was the first Swedish report we found on this subject.

As for the antigen panel, some selection is mandatory; otherwise one would have to include all possible microorganisms in it. Rhizopus, Paecilomyces and Mucor were not included because they were not predominant microorganisms in the air samples. The microbial flora of the work environment in the saw mill had certain similarities to that of Finnish farm buildings and therefore the antigen panel for farmer's lung was used. It consisted of Micropolyspora faeni, Thermoactinomyces vulgaris, and Aspergillus fumigatus.

One also should keep in mind that the presence of antigen specific precipitating antibodies in the serum only indicates exposure to the offending antigens. So precipitin tests are only one aid in the characterization of exposure and may give some support to the diagnosis. We think that it is at least as important to know what really is found in the ambient air of the environment. Aerobiological methods are a further step towards the etiologic diagnosis, but even the combined data of aerobiological and serological analyses do not provide final confirmation to the etiology.

\section{References}

1. Hapke EJ, Seal RME, Thomas GO, Hayes M, Meek JC. Farmer's lung: A clinical, radiographic, functional and serological correlation of acute and chronic stages. Thorax 27 (1968) 451-468.

2. MRC Symposium. Humidifier fever. Thorax 32 (1977) $653-663$.

Erkki O Terho, MD

Department of Pulmonary Diseases

University Central Hospital

Kuopio, Finland

Kaj Husman, MD, \& Marjut Kotimaa, BA Kuopio Regional Institute of Occupational Health

Kuopio, Finland

and

Tom Sjöblom, MD

A Ahlström Ltd

Varkaus, Finland 